\title{
Levels of metabolizable energy and digestible lysine for broiler chicks 8-21 days of age
}

\section{Níveis de energia metabolizável e lisina digestível para pintos de corte de 8 a 21 dias de idade}

\author{
Ricardo Vianna Nunes ${ }^{1 *}$; Thaís Lorana Savoldi²; Claudio Yuji Tsutsumi; \\ Sharon Karla Luders Meza ${ }^{4}$ Jomara Broch ${ }^{5}$; Cleison de Souza ${ }^{5}$; \\ Jeffersson Rafael Henz ${ }^{6}$; Cleverson de Souza ${ }^{7}$
}

\begin{abstract}
The experiment was conducted with the objective of evaluating the effect of metabolizable energy (ME) levels and digestible lysine (DL) levels on the performance of 8-21 days old broiler chicks. Eight hundred and sixty four broiler chicks were used, with average weight of $160 \pm 5 \mathrm{~g}$, randomly distributed in 48 boxes (experimental unit), experimental unit in a factorial $4 \times 4$ with four levels of $\operatorname{ME}(2,700,2,825,2,950$, and 3,075 kcal kg-1) and four levels of DL $(1,080 ; 1,187 ; 1,295$ and 1,403\%) resulting in 16 treatments with three replications. Increases in levels of ME and DL in the diets caused significant interaction $(\mathrm{P}<0.05)$ in weight gain and feed conversion. Increasing levels of ME and DL caused significant interaction $(\mathrm{P}<0.05)$ for the deposition rate of protein and fat in the carcass. The simultaneous increases of ME and DL in the diet promoted a linear increase $(\mathrm{P}<0.05)$ in villus height of the duodenum, jejunum, and villous:crypt ileum. It is recommended the use of $3,075 \mathrm{kcal} \mathrm{kg}^{-1} \mathrm{ME}$ and $1,403 \%$ of $\mathrm{LD}$ for best performance, protein deposition rate, and intestinal morphometric characteristics of 8-21 days old broiler chicks.
\end{abstract}

Key words: Performance, broiler, intestinal morphology

\section{Resumo}

O experimento foi conduzido com o objetivo de avaliar o efeito dos níveis de energia metabolizável (EM) e de lisina digestível (LD) no desempenho de pintos de corte de 8 a 21 dias de idade. Foram utilizados 864 pintos de corte, com peso médio de $160 \pm 5 \mathrm{~g}$, distribuídos em um delineamento inteiramente casualizado ao acaso, em 48 boxes (unidade experimental), e esquema fatorial $4 \mathrm{x} 4$ sendo quatro níveis de $\operatorname{EM}\left(2.700 ; 2.825 ; 2.950\right.$; e $\left.3.075 \mathrm{kcal} \mathrm{kg}^{-1}\right)$ e quatro níveis de LD $(1,080 ; 1,187 ; 1,295$ e $1,403 \%)$ resultando em 16 tratamentos com três repetições. Os aumentos dos níveis de EM e de LD nas rações promoveram interação $(\mathrm{P}<0,05)$ no ganho de peso, conversão alimentar, taxa de deposição de proteína

1 Prof. Dr., Programa de Pós-Graduação Stricto sensu em Zootecnia, Universidade Estadual do Oeste do Paraná, UNIOESTE, Marechal Cândido Rondon, PR, Brasil. E-mail: nunesrv@hotmail.com

2 M.e em Zootecnia, Prof ${ }^{a}$ do Curso de Medicina Veterinária, Universidade Estadual de Maringá, UEM, Umuarama, PR, Brasil. E-mail: thaislorana@hotmail.com

3 Prof. Dr., Curso de Agronomia, UNIOESTE, Marechal Cândido Rondon, PR, Brasil. E-mail: claudio.tsutsumi@unioeste.br

4 M.e em Zootecnia, Umuarama, PR, Brasil. E-mail: shakavet@hotmail.com

5 Discentes do Curso de Mestrado do Programa de Pós-Graduação Stricto sensu em Zootecnia, UNIOESTE, Marechal Cândido Rondon, PR, Brasil. E-mail: brochjomara@yahoo.com.br; cleisondsz@hotmail.com

6 M.e em Zootecnia, Cooperativa Primato, Nova Santa Rosa, PR, Brasil. E-mail: jeffersson_henz@hotmail.com

7 Discente do Curso de Doutorado do Programa de Pós-Graduação Stricto sensu em Ciência Animal, Universidade do Estado de Santa Catarina, UDESC, Lages, SC, Brasil. E-mail: cleversonsz@hotmail.com

* Author for correspondence 
e na taxa de deposição de gordura na carcaça. Os aumentos simultâneos da EM e da LD na ração, promoveram aumento linear $(\mathrm{P}<0,05)$ na altura de vilosidade do duodeno, jejuno e relação vilo:cripta do íleo. Recomenda-se o uso de $3.075 \mathrm{kcal} \mathrm{kg}^{-1}$ de EM e 1,403\% de LD, para melhor desempenho, taxa de deposição de proteína e características morfométricas intestinais de pintos de corte de 8 a 21 dias de idade.

Palavras-chave: Desempenho, frango de corte, morfometria intestinal

\section{Introduction}

The continued breeding of broilers makes necessary the constant development of studies on their nutritional requirements. Pre-starting phases and initial requirements are greater, and efficiency of use of amino acids is associated with increased muscle mass and nitrogen retention (NAMAZU et al., 2008).

Several studies have shown improvements in productive performance and feed conversion ratio of broilers, in relation to the energy of the diet. Mendonça et al. (2007) verified that in broilers increased dietary metabolizable energy consumption decreased, but energy intake increased. Therefore, in the current genetic lineages adjustments in the density of the rations must be made in order to allow for their nutritional needs, especially in conditions of high ambient temperature.

Diets for chickens have been formulated on the basis of ideal protein; the balance of amino acids preventing its deficiency or excess. This concept is based on the lysine, which is considered the second essential amino acid for birds. Because there is no necessary synthesis of amino acid to meet the needs of organic birds, this must be included in feed (HAESE et al., 2012).

Another very important factor in nutrition is the structure and integrity of the intestinal epithelium of the birds, which influence the use of foods (VIEIRA et al., 2006). Baurhoo et al. (2007) reported that the development of mucosal villi directly affects intestinal health, besides increasing the absorption of nutrients, and therefore presents a greater absorption area. The development consists of increasing the height and density of the intestinal villi, which corresponds to a greater number of epithelial cells, and to an increase in gastrointestinal and bowel absortiva capacity.

Thus, the objective of this paper is to evaluate four levels of metabolizable energy and digestible lysine in terms of performance, rate of deposition of protein, fat on the carcass, and morphometric characteristics of the small intestine of chicks in the initial phase.

\section{Material and Methods}

This study was conducted at the Experimental Station of poultry farming at Universidade Estadual do Oeste do Paraná-UNIOESTE, following approval by the Committee of Ethics and Biosecurity of the institution (Protocol \# 04511). The trial shed used was built of masonry, 20 meters long and 8 meters wide, and divided into boxes of $1.76 \mathrm{~m} 2$. Each box (experimental unit - EU) had a tubular feeder, water trough, nipple type hopper for heating (250 Watt infrared bulbs), and concrete floor, which was lined with pine shavings.

Eight hundred and sixty four male slitting chicks were used from seven days of age; the Cobb 500 lineage with initial average weight $160 \pm 5 \mathrm{~g}$. The treatments were distributed in a completely randomized experimental design in a factorial scheme $4 \times 4$, consisting of four levels of metabolizable energy (ME) $(2700,2825,2950$, and $\left.3075 \mathrm{kcal} \mathrm{kg}^{-1}\right)$ and four levels of digestible lysine (LD) $(1.080,1.187,1.295$, and $1.403 \%)$, totaling 16 treatments with three repetitions and 18 birds by EU. After the distribution of birds, an additional middleweight $(160 \pm 5 \mathrm{~g})$ group of five birds were selected, maintained in fasting, slaughtered and then milled, pre-dried, and pre-degreased, before 
performing the analysis of dry matter, fat, and protein, according to de Silva and Queiroz (2002) methodologies.

Throughout the experimental period there was monitoring of ambient temperature, which ranged in thermal recommendations for phase (maximum $30,34^{\circ} \mathrm{C}$ and minimum $23,28^{\circ} \mathrm{C}$ ). The experimental diets were formulated based on corn and soybean meal (table 1), in accordance with the composition of the feed and nutritional requirements proposed by Rostagno et al. (2011), keeping the relationships of protein ideal for metioninacistina (71), tryptophan (16), threonine (65), arginine (105), isoleucine (65), and valine (75).

At 21 days of age the birds and the feeders were heavy for the determination of weight gain, feed intake, and feed conversion. On the plots in which mortality occurred, feed intake and feed conversion were adjusted according to Sakomura and Rostagno (2007).

After weighing, two birds by the EU, with a variation of \pm 10 of weight per treatment, were maintained fasting for 6 hours after which they were again weighed and sacrificed by cervical dislocation for body composition assessment of housing.

Additional groups and carcases of slaughtered poultry for 21 days were identified and ground individually by experimental unit, then homogenised. A sample of each ground bird was sent to the lab for realization of kiln pre-drying forced ventilation, 55C for 72 hours, and subsequently pre-fat in Soxhlet-type device as described by Silva and Queiroz (2002), ground into ball type mill and subjected to analysis of dry matter, crude protein, and ether extract (SILVA; QUEIROZ, 2002).

For the purpose of determining the rates of deposition of protein (TDP) and fat (gdia) the methodology was adapted from Fraga et al. (2008). The TDP was measured by comparing the slaughtered chicks at the end of the experimental period (21 days of age) with an additional group.
Furthermore, the two other 21-day-old birds in each experimental unit, with the average weight of the plot $( \pm 10)$, were slaughtered for the evaluation of histomorphometry of the small intestine. The segments of the small intestine (duodenum, jejunum, and ileum) were opened in the mesenteric region and fragments approximately $2.0 \mathrm{~cm}$ long were carefully collected, washed in distilled water, extended by the tunica serosa, and fixed in buffered formalin solution 10 by 24 hours. After this period, the fragments underwent several washes with 70 alcohol and kept in this solution until the preparation of the blades. Subsequently, these were dehydrated in growing alcohol solutions, diaphanized in xylene, included in paraffin and cut with a rotary microtome $7 \mu \mathrm{m}$. Three blades per animal were prepared and in each blade four semisseriados were placed, and a cut between the 12 cuts. The sections were stained with hematoxylin-eosin.

Morphometric analysis of the histological sections were performed in image Analyzer Motic Advanced 2.0. Straight lengths were selected and measured in each intestinal region of each bird, according to the adopted unit $(\mu \mathrm{m})$ of 30 villi and crypts, 30 targeted. Villus height measurements were taken from the upper base of the crypt to the apex of the villi and crypts were measured between the villi of the lower base to the upper base of the crypt.

Statistical analyses were performed with the aid of the program Statistical Analysis System version 8 (SAS, 2001). The analyses of the parameters evaluated were undertaken by PROC GLM procedure $(\mathrm{P} \leq 0.05)$. In the parameters in which differences were found $(\mathrm{P} \leq 0.05)$ polynomial regression was estimated using the procedure PROC REG to metabolizable energy interactions $\mathrm{x}$ digestible lysine $(\mathrm{P} \leq 0.05)$. Regressions of response surface were estimated using the procedure PROC RSREG as adjustment of data. 


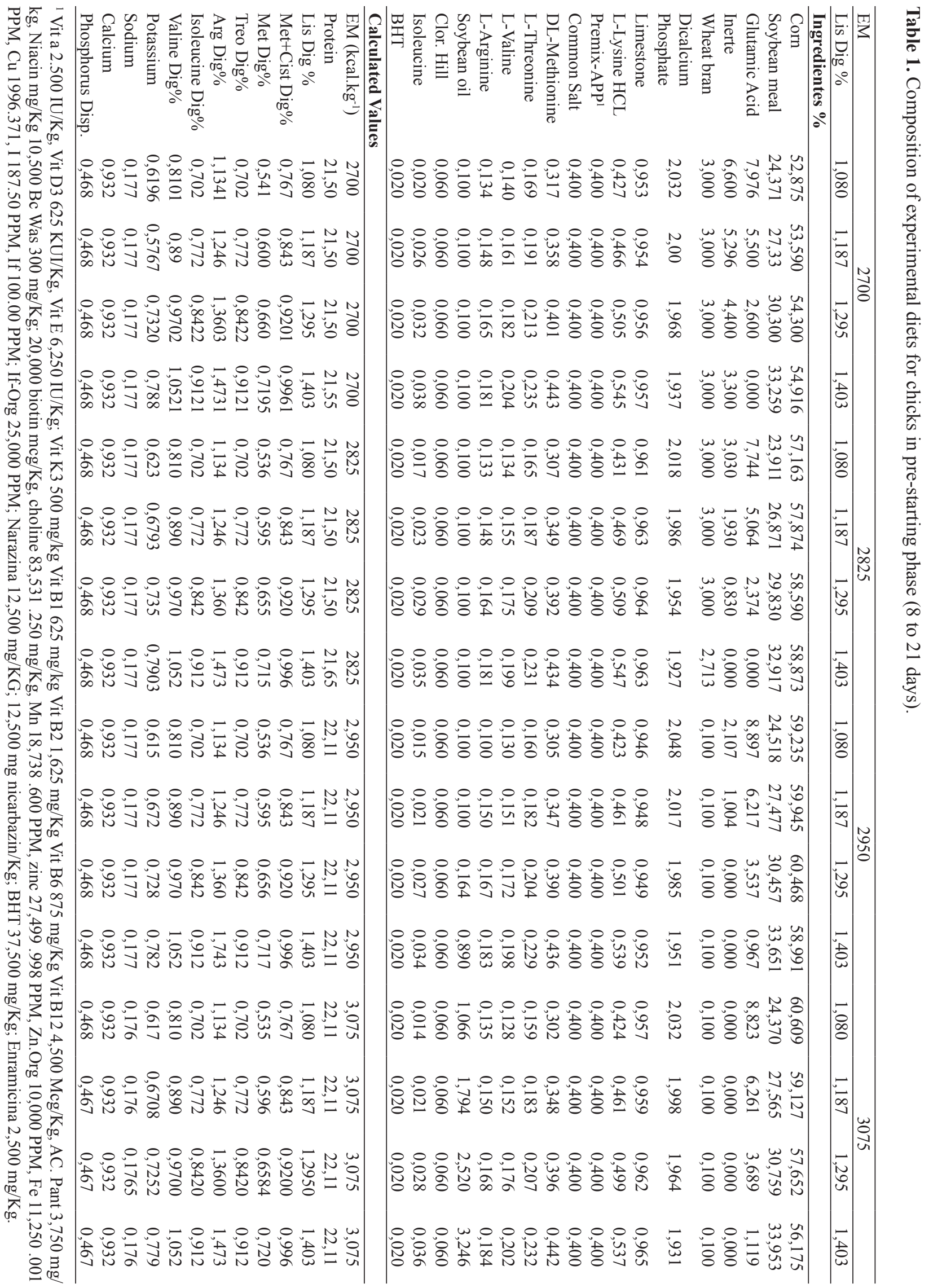




\section{Results and Discussion}

There was interaction between levels of metabolizable energy (me) and digestible lysine (LD) on the weight gain of chicks (table 2), expressed by the equation of response surface (SR), $\mathrm{GP}=7664.695984-5.505093 * \mathrm{EM}+475.666044 *$ $\mathrm{LD}+0.000995^{*} \mathrm{EM}^{2}+0.006862 * \mathrm{EM}^{*} \mathrm{LD}-$
$174.738215 * \mathrm{LD}^{2},\left(\mathrm{R}^{2}=0.67\right)$ (figure 1). The weight gain increased as there was an increase in levels and LD, but greater effect in levels was observed. The increased weight gain in broilers in the initial phase could be due to the increase in protein deposition due to the gradual improvement of the energy relationship: protein diet (CORRÊA et al., 2007).

Table 2. Performance of early-stage cutting chicks fed diets with increasing levels of metabolizable energy and digestible lysine.

\begin{tabular}{cccc}
\hline & Weight gain $(\mathrm{g})$ & Feed intake $(\mathrm{g} /$ ave $)$ & Feed Conversion $(\mathrm{g} / \mathrm{g})$ \\
\hline EM & & & \\
2700 & 512,16 & 830,37 & 1,31 \\
2825 & 508,86 & 818,08 & 1,26 \\
2950 & 554,96 & 797,01 & 1,21 \\
3075 & 602,28 & 848,43 & 1,15 \\
\hline \multicolumn{5}{c}{} & $\mathrm{ns}$ & \\
\hline LD & & \\
$1,080 \%$ & 537,00 & 826,10 & 1,25 \\
$1,187 \%$ & 537,27 & 797,52 & 1,21 \\
$1,295 \%$ & 550,85 & 835,30 & 1,27 \\
$1,403 \%$ & 554,80 & 816,85 & \\
\hline & & ns & SR \\
\hline EM x LD & SR & 1,21 & 1,20 \\
\hline CV $(\%)$ & 1,94 & 818,94 & 1,23 \\
Average & 544,98 & ns & \\
\hline
\end{tabular}

CV: coefficient of variation; 1SR: response surface. 1NS: not significant. GP7664 .695984 -5, 505093EM475, 666044LD0, 000995EM20, 006862EMLD-174, 738215LD2 (R20 .78); CA 7.1631620, 002573LD-11, 926879EM-0, 000000723EM20, 000526EMLD4, 047968LD2 (R20 .66).

Haese et al. (2012), when assessing the nutritional requirements of LD and nutritional plans for male broilers based on ideal protein, observed that the ideal level for better weight gain of chicks from 1 to 21 days of age was 1.3. Furthermore, Cella et al. (2009), who studied four levels of LD (1.14, $1.22,1.26$, and 1.18) in male broilers of the same age ( 1 to 21 days), observed that the weight gain was influenced by quadratic form, increasing to the level of 1.183. Savoldi el al. (2012), working with chickens from 1 to 10 days of age, did not observe between levels of interaction in and LD, and the results of weight gain indicated a requirement for LD and $3075 \mathrm{kcal} 1.27 \mathrm{in}$.
In an experiment conducted by Takeara et al. (2010), evaluating the effect of levels of LD (1.05, $1.10,1.15,1.20$, and 1.25) on the performance of broilers from 12 to 22 days, they observed that decreasing levels of LD linearly reduced performance. For broilers 22 to 42 days of age, Conhalato et al. (1999) recommended 1.02 and 0.98 of LD, nominees for improvement in performance variables weight gain and feed conversion ratio, respectively. According to the same authors, the differences in the results of performance in different jobs are due to several factors such as differences in the digestible amino acids composition of the rations, the lines, and the sex of broilers. 
Figure 1. Weight gain of broilers from 8 to 21 days according to the levels of metabolizable energy and digestible lysine in the diet.

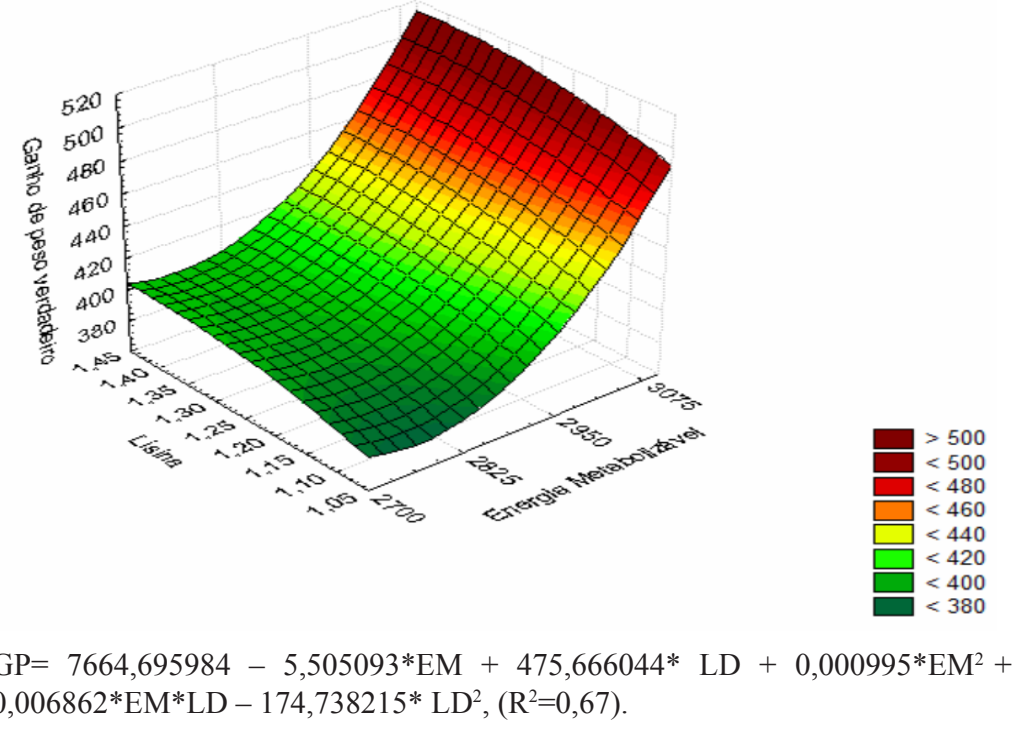

Levels of metabolizable energy and digestible lysine exerted no effect on feed intake of cutting chicks in the studied period. However, there was interaction between the levels of LD and EM to CA (table 2), expressed by the equation of SR, $\mathrm{CA}=7.163162+0.002573 * \mathrm{LD}-11.926879 * \mathrm{EM}$
$-0.000000723 * \mathrm{EM}^{2}+0.000526 * \mathrm{EM}^{*} \mathrm{LD}+$ $4.047968 * \mathrm{LD}^{2},\left(\mathrm{R}^{2}=0.66\right)$, observing improvement in its index as levels and LD of ration increased (figure 2). Haese et al. (2012) argued that the voluntary intake of food is influenced by the level of LD, as well as the imbalance of amino acids of feed and energy levels of diets.

Figure 2. Broiler feed conversion ratio of 8 to 21 days according to the levels of metabolizable energy and digestible lysine ration.

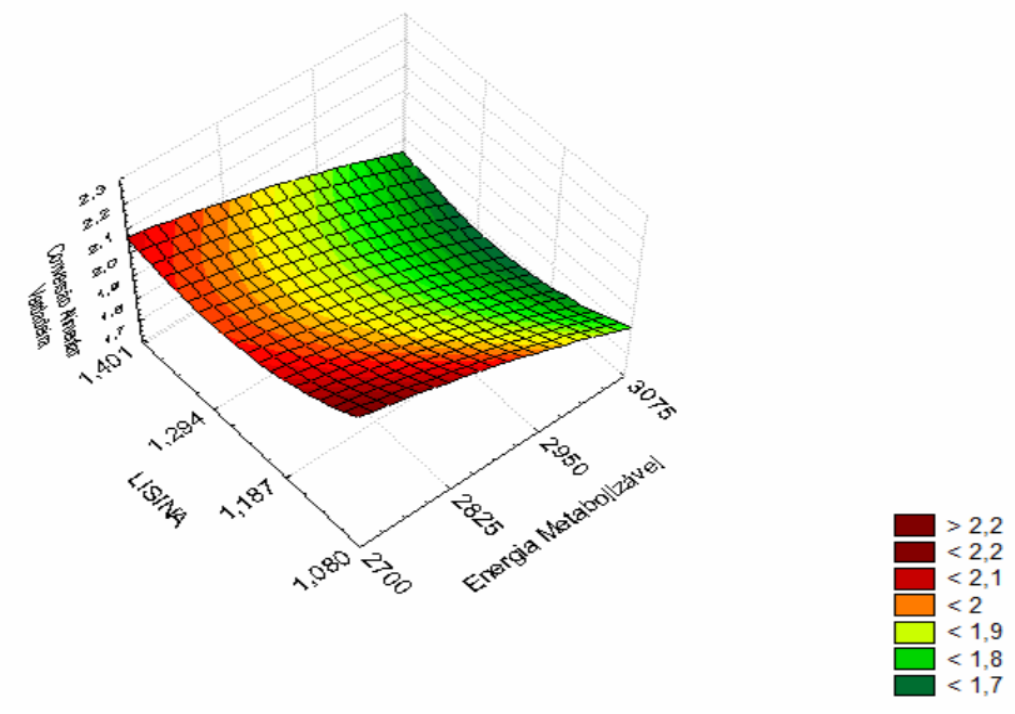

$\mathrm{CA}=7,163162+0,002573 * \mathrm{LD}-11,926879 * \mathrm{EM}-0,000000723 * \mathrm{EM}^{2}+$ $0,000526 * \mathrm{EM}^{*} \mathrm{LD}+4,047968^{*} \mathrm{LD}^{2},\left(\mathrm{R}^{2}=0,66\right)$. 
There was significant interaction levels of $+0.005211 * \mathrm{LD} * \mathrm{EM}+9.009820 * \mathrm{LD}^{2},\left(\mathrm{R}^{2}=0.25\right)$ metabolizable energy and digestible lysine on (figure 3). The rate of deposition of body fat (TDG) deposition rate of protein and fat (table 3). The is expressed by the equation TDG $=-67.652002+$ response to the rate of deposition of protein (TDP) $\quad 0.042688^{*} \mathrm{EM}+5.083384 * \mathrm{LD}-0.000007053^{*} \mathrm{EM}^{2}$ was expressed by the equation TDP $=90.138586-\quad+0.001956 * \mathrm{LD} * \mathrm{EM}-4.161409 * \mathrm{LD}^{2},\left(\mathrm{R}^{2}=0.40\right)$ $0,046651 * \mathrm{EM}-34.891458 * \mathrm{LD}+0.000007164 * \mathrm{EM}^{2} \quad$ (figure 4).

Table 3. Deposition rate of protein (TDP) and fat deposition rate (TDG) of cutting chicks initially fed diets with increasing levels of metabolizable energy and digestible lysine.

\begin{tabular}{lccc}
\hline & & $\begin{array}{c}\text { TDP } \\
(\mathrm{g} / \text { dia })\end{array}$ & $\begin{array}{c}\text { TDG } \\
(\mathrm{g} / \text { dia })\end{array}$ \\
\hline EM & & & \\
& 2700 & 4,592 & 2,660 \\
& 2825 & 4,632 & 3,132 \\
& 2950 & 4,516 & 4,150 \\
& 3075 & 5,105 & 4,123 \\
\hline LIS & & & \\
& $1,080 \%$ & 4,405 & 3,415 \\
& $1,187 \%$ & 4,443 & 3,598 \\
& $1,295 \%$ & 4,770 & 3,477 \\
\hline EM*LIS & $1,403 \%$ & 5,212 & 3,555 \\
\hline CV(\%) & & SR* & SR* \\
Average & & 13,45 & 20,63 \\
\hline
\end{tabular}

CV coefficient of variation; MR response surface; TDP 90.138586-0, 046651EM-34, 891458LD 0, 000007164EM2 0, 005211LDEM 9, 009820LD2 (R20 .25); TDG -67.652002 0, 042688EM 5, 083384LD-0, 000007053EM2 0, 001956LDEM-4, 161409LD2 (R20 .40).

Figure 3. Body protein deposition rate of broilers from 8 to 21 days according to the levels of metabolizable energy and digestible lysine ration.

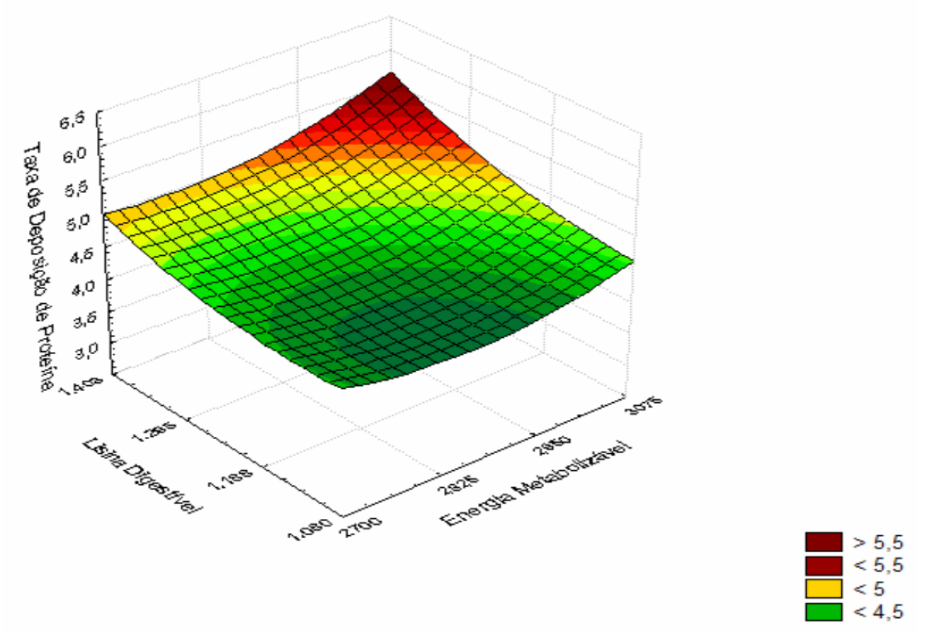

$\mathrm{TDP}=90,138586-0,046651 * \mathrm{EM}-34,891458 * \mathrm{LD}+0,000007164 * \mathrm{EM}^{2}+$ $0,005211 * \mathrm{LD} * \mathrm{EM}+9,009820 * \mathrm{LD}^{2},\left(\mathrm{R}^{2}=0,25\right)$. 
Figure 4. Body fat deposition rate of broilers from 8 to 21 days according to the levels of metabolizable energy and digestible lysine ration.

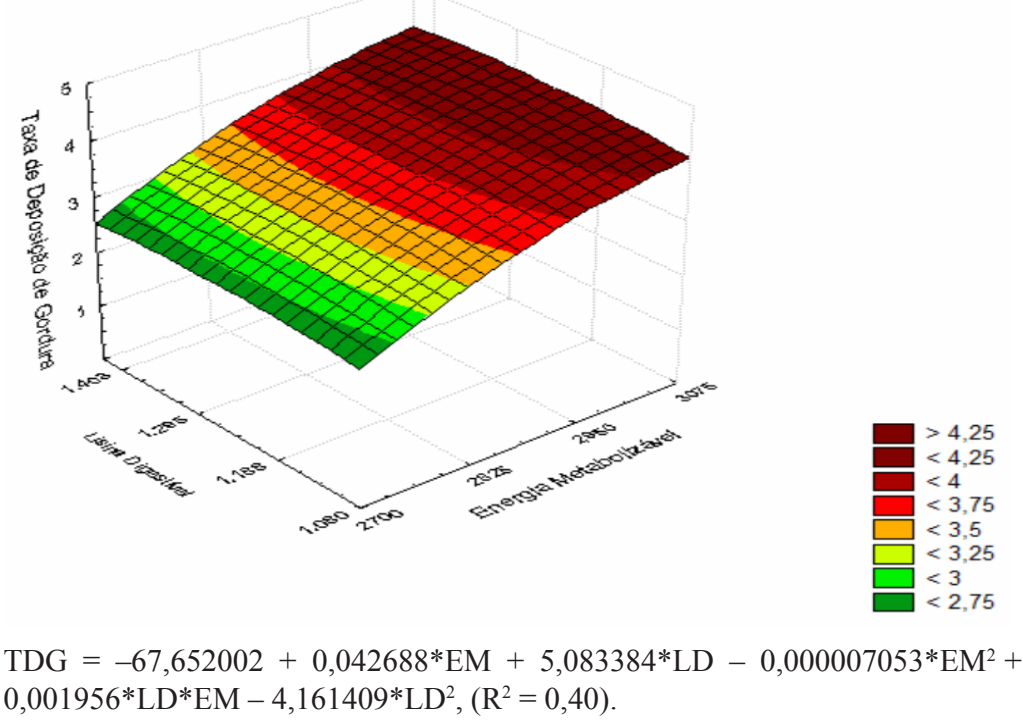

The largest protein deposition in housing occurred as levels and LD in the rations increased. However, for the rate of deposition of body fat increased levels were primarily responsible for its higher deposition. Sakomura et al. (2004) noted that greater levels of energy $\left(3,350 \mathrm{kcal} \mathrm{kg}^{-1}\right)$ provided better performance results for chickens; the 3,200 level $\mathrm{kcal} \mathrm{kg}^{-1}$ promoted better balance in the use of energy for the deposition of protein and fat on the carcass. The improvement in performance associated with the supplementation of fat in the diet may be due to the extra caloric effect, namely, increased availability of nutrients of the feed ingredients, as well as the extra fat metabolic effect, which improves energy efficiency by increasing the net energy ration (FREITAS et al., 2005).
There was significant interaction levels of metabolizable energy and digestible lysine on some morphometric characteristics of the small intestine (table 4). The height of the villi of the duodenum was higher as levels and LD increased $(\mathrm{AVD}=2771.7738-1.9434 * \mathrm{EM}+1186.6879 * \mathrm{LD}$ $+0.0003 * \mathrm{EM}^{2}+0.2766 * \mathrm{EM}^{*} \mathrm{LD}-606.4979 * \mathrm{LD}^{2}$; $\left(\mathrm{R}^{2}=0.34\right)$ (figure 5). In the jejunum (AVJ = $-10509.9852+0.523 * \mathrm{EM}+16168.6627 * \mathrm{LD}+$ $0.0009 * \mathrm{EM}^{2}-4.4578 * \mathrm{EM}^{*} \mathrm{LD}-1141.9585 * \mathrm{LD}$ 2; $\left(\mathrm{R}^{2}=0.44\right)$ villus heights were higher as the level increased and the level of LD rations reduced. Note that the reduction in levels and the increase in LD also provided greater height of villi in the jejunum (figure 6). In the ileum no significant differences were observed in their heights, depending on levels and LD of the feed. 
Figure 5. Height of villi in duodenum depending on levels of metabolizable energy and digestible lysine.

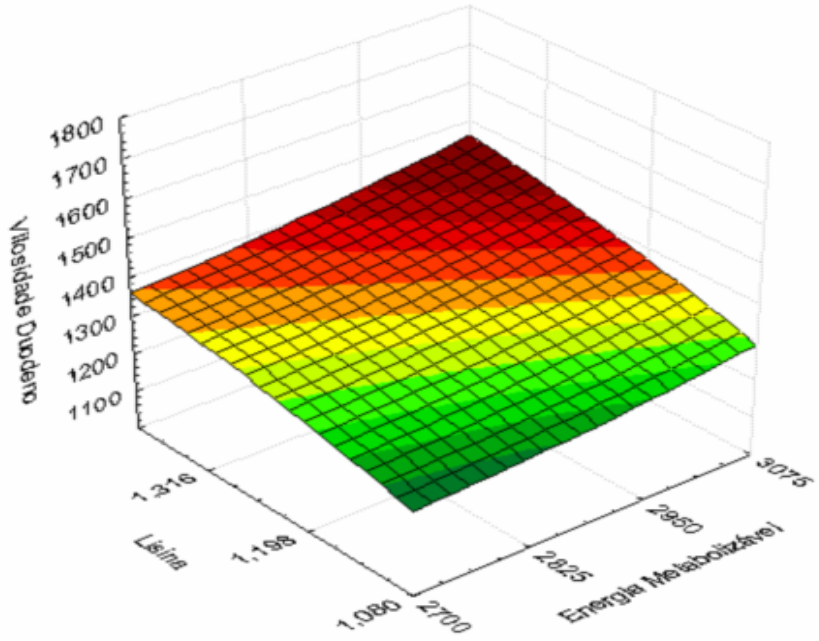

$>140$

$<1400$

$\left(\mathrm{AVD}=2771,7738-1,9434 * \mathrm{EM}+1186,6879 * \mathrm{LD}+0,0003 * \mathrm{EM}^{2}+0,2766 * \mathrm{EM} * \mathrm{LD}-\right.$ $\left.606,4979 * \mathrm{LD}^{2} ; \mathrm{R}^{2}=0,34\right)$.

Figure 6. Height of villi in the jejunum in function levels of metabolizable energy and digestible lysine.

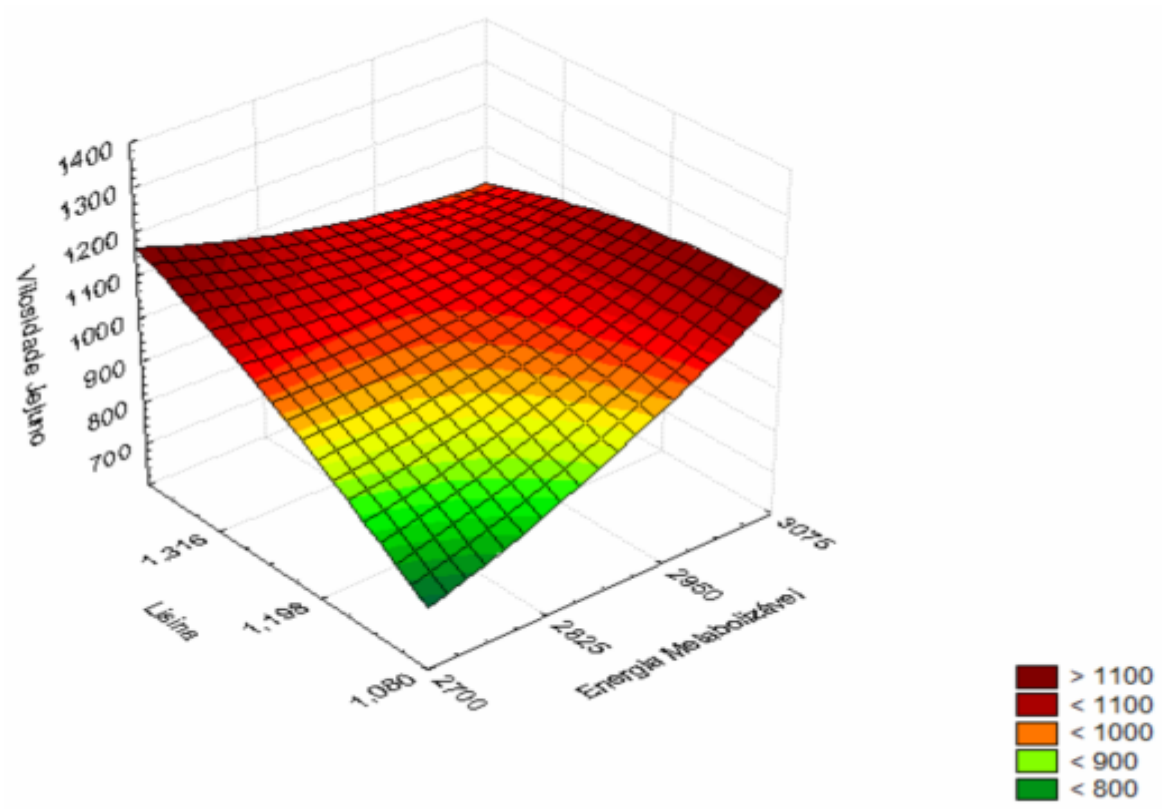


Table 4. Averages of the intestinal morphology of broilers from 8 to 21 days according to the levels of metabolizable energy and digestible Lysine in the diet.

\begin{tabular}{|c|c|c|c|c|c|c|c|c|c|}
\hline & \multicolumn{3}{|c|}{ Duodenum } & \multicolumn{3}{|c|}{ Jejunum } & \multicolumn{3}{|c|}{ Ileum } \\
\hline & $\begin{array}{l}\text { Vilo } \\
(\mu \mathrm{m})\end{array}$ & $\begin{array}{l}\text { Crypt } \\
(\mu \mathrm{m})\end{array}$ & $\begin{array}{l}\text { Vilo: } \\
\text { Crypt }\end{array}$ & $\begin{array}{l}\text { Vilo } \\
(\mu \mathrm{m})\end{array}$ & $\begin{array}{l}\text { Crypt } \\
(\mu \mathrm{m})\end{array}$ & $\begin{array}{l}\text { Vilo: } \\
\text { Crypt }\end{array}$ & $\begin{array}{l}\text { Vilo } \\
(\mu \mathrm{m})\end{array}$ & Crypt $(\mu \mathrm{m})$ & $\begin{array}{l}\text { Vilo: } \\
\text { cripta }\end{array}$ \\
\hline \multicolumn{10}{|l|}{ EM } \\
\hline 2700 & 1293,23 & 246,60 & 5,36 & 968,60 & 184,69 & 5,53 & 717,94 & 186,89 & 3,91 \\
\hline 2825 & 1326,09 & 255,54 & 5,30 & 975,03 & 218,88 & 4,58 & 730,50 & 202,55 & 3,72 \\
\hline 2950 & 1335,05 & 295,09 & 4,91 & 1018,15 & 271,53 & 4,05 & 731,62 & 213,75 & 3,54 \\
\hline 3075 & 1387,77 & 249,15 & 5,64 & 1082,13 & 262,05 & 4,34 & 721,22 & 205,37 & 3,57 \\
\hline Regressions EM & & ns & ns & & $\mathrm{L}^{* *}$ & $\mathrm{~L}^{* *}$ & ns & ns & \\
\hline \multicolumn{10}{|l|}{ LD } \\
\hline 1,080 & 1261,51 & 249,69 & 5,19 & 916,58 & 220,87 & 4,33 & 704,62 & 206,70 & 3,57 \\
\hline 1,187 & 1285,78 & 253,39 & 5,14 & 1019,32 & 221,67 & 4,88 & 746,67 & 208,40 & 3,67 \\
\hline 1,295 & 1398,95 & 290,45 & 5,21 & 1028,95 & 271,02 & 4,08 & 738,72 & 213,07 & 3,54 \\
\hline 1,403 & 1395,89 & 252,85 & 5,65 & 1079,05 & 223,58 & 5,22 & 711,26 & 180,38 & 3,96 \\
\hline Regressions LD & & ns & ns & & ns & ns & ns & ns & \\
\hline EM x LD & SR & & & SR & & & & & SR \\
\hline CV\% & 9,97 & 24,23 & 19,78 & 12,24 & 25,70 & 26,02 & 7,35 & 16,25 & 14,54 \\
\hline Média & 1335,53 & 261,59 & 5,30 & 1010,97 & 234,29 & 4,63 & 725,32 & 202,14 & 3,68 \\
\hline
\end{tabular}

CV coefficient of variation, not significant ns Lefeito linear probability 1, MR response surface; AVD 2771.7738-1, 9434EM, 0, 6879LD 1186 0003EM2 0, 2766EMLD-606, 4979LD2 (R20 .34); AVJ -10509.9852 0, 523EM 0, 6627LD, 16168 0009EM2-4, 4578EMLD-1141, 9585LD2 (R20 .44); JCP-423.40369 0, 22777EM (R20 .89); RVCJ -179.07235-0, 11782EM 0, 00001983EM2 (R20 .98); 78.7802 VCI-0, 0335EM-42, 0989LD 3, 6872EM-6EM2 0, 0091EMLD 6, 8126LD2 (R20 .34).

Maiorka et al. (2002) reported that the number and size of villi in each segment of the small intestine confer characteristics; namely, in the presence of nutrients absortiva capacity of the segment will be directly proportional to the number of villi present, size of the villi, and surface area available for absorption. However, the morphological alterations in the gastrointestinal tract cannot by itself explain a total increase in ability to digest and absorb nutrients, because digestive processes are highly dependent on the pancreatic and intestinal enzyme activity.

No differences were found in terms of the depth of the crypt in the duodenum and ileum, depending on levels and LD studied. However, in the jejunum, the crypt depth was greater as levels of metabolizable energy rations increased (PCJ = $-423.40369+0.22777 * E M ;\left(\mathrm{R}^{2}=0.89\right)$. As noted by Viola and Vieira (2007), the depths of crypts are measures of cell proliferation, and shallower crypts indicate better intestinal health.
In the duodenum, the relative height of villi: crypt depth did not show differences in relation to the experimental treatments. However, in the jejunum, the levels of metabolizable energy exerted a quadratic effect RVCJ $=-179.07235-0.11782 * \mathrm{EM}$ $+0.00001983^{*} \mathrm{EM}^{2} ; \quad\left(\mathrm{R}^{2}=0.98\right)$. According to Arruda et al. (2008), the relationship of vilo: crypt is an indicator of the digestive capacity of the small intestine, and the increase in this ratio corresponds to the best ability of digestion and absorption and lower energy losses. Therefore, it is considered a good indication of the digestive efficiency of Ave. and the best relationship of vilo: crypt is obtained with the level of in of $2971 \mathrm{kcal} \mathrm{kg}^{-1}$, i.e. the best digestive capacity.

However, there was significant ileum interaction between the levels and LD for this variable $(\mathrm{VCI}=$ $78.7802-0.0335 * \mathrm{EM}-42.0989 * \mathrm{LD}+3.6872 * \mathrm{EM}$ $-6 * \mathrm{EM}^{2}+0.0091 * \mathrm{EM} * \mathrm{LIS}+6.8126^{*} \mathrm{LIS}^{2}$; $\left(\mathrm{R}^{2}=0.34\right.$ ) (figure 7). Greater relationship was 
observed in the crypt with ileum villi: increased levels of metabolizable energy and digestible lysine. This result was also observed for reduction in levels in the diet. Higher levels in lower LD reduced this relationship, demonstrating its biggest effect on this variable.

Figure 7. Villi: crypt of the ileum in function levels of metabolizable energy and digestible lysine.

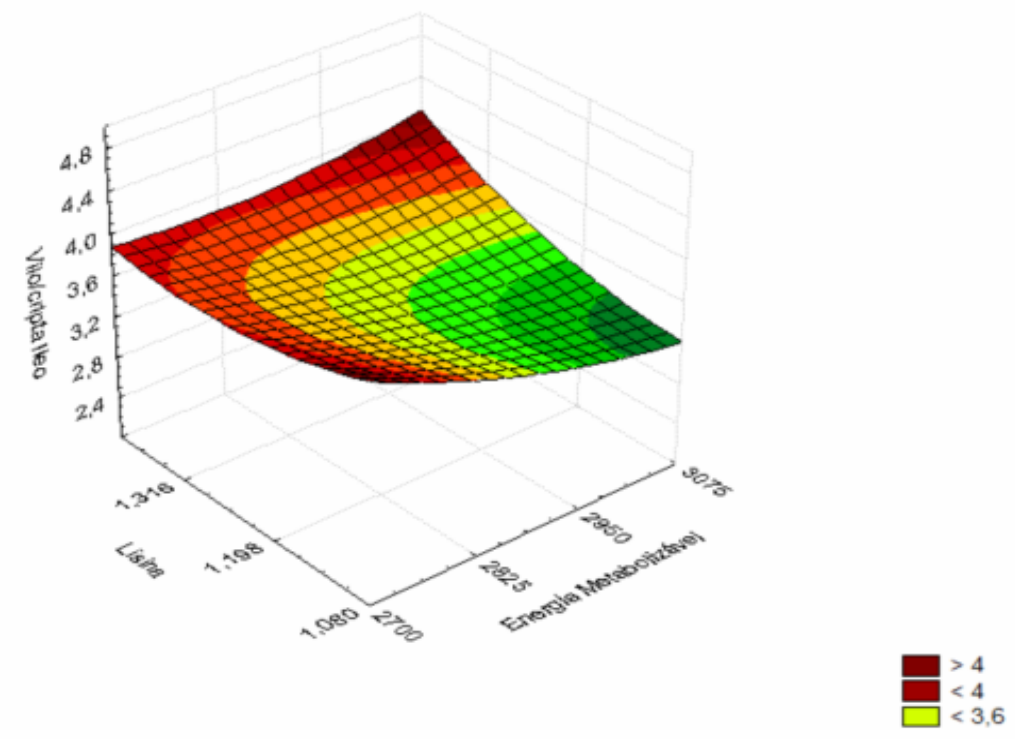

\section{Conclusions}

Rations with 3,075 $\mathrm{kcal} \mathrm{kg}^{-1}$ of in and LD 1.403 provided better performance, rate of deposition of protein, and morphometric characteristics of intestinal chicks 8 to 21 days of age.

\section{References}

ARRUDA, A. M. V.; FERNANDES, R. T. V.; SILVA, J. M.; LOPES, D. C. Avaliação morfo-histológica da mucosa intestinal de coelhos alimentados com diferentes níveis e fontes de fibra. Revista Caatinga, Mossoró, v. 21, n. 2, p. 1-11, 2008.

BAURHOO, B.; PHILlIP, L.; RUIZ-FERIA, C. A. Effects of purified lignin and mannan oligosaccharides on intestinal integrity and microbial populations in the ceca and litter of broiler chickens. Poultry Science, Champaign, v. 86, n. 6, p. 1070-1078, 2007.

CELlA, P. S.; MURAKAMI, A. E.; FRANCO, J. R. G. Níveis de lisina digestível em dietas baseadas no conceito de proteína ideal para frangos de corte na fase inicial. Ciência Animal Brasileira, Goiás, v. 10, n. 1, p. 101-106, 2009.
CONHALATO, G. S.; DONZELE, J. L.; ALBINO, L. F. T.; OLIVEIRA, R. F. M.; FONTES, D. O. Níveis de lisina digestível para frangos de corte machos na fase de 22 a 42 dias de idade. Revista Brasileira de Zootecnia, Viçosa, MG, v. 28, n. 1, p. 98-104, 1999.

CORRÊA, G. S. S.; SILVA, M. A.; CORRÊA, A. B.; FONTES, D. O; TORRES, R. A.; DIONELLO, N. J. L; SANTOS, G. G; FREITAS, L. S. Exigência de proteína bruta e energia metabolizável para codornas de corte EV1. Arquivo Brasileiro Medicina Veterinária Zootecnia, Belo Horizonte, v. 59, n. 3, p. 797-804, 2007.

FRAGA, A. L.; MOREIRA, I.; FURLAN, A. C.; BASTOS, A. O.; OLIVEIRA, R. P.; MURAKAMI, A. E. Lysine requirement of start barrow from two genetic groups fed on low crude protein diets. Brazilian Archives of Biology and Technology, Curitiba, v. 51, n. 1, p. 49-56, 2008.

FREITAS, E. R.; SAKOMURA, N. K.; NEME, R.; BARBOSA, N. A. A. Valor nutricional do milho termicamente processado, usado na ração pré-inicial para frangos de corte. Arquivo Brasileiro de Medicina Veterinária e Zootecnia, Belo Horizonte, v. 57, n. 7, p. 510-517, 2005. 
HAESE, D.; KILL, J. L.; HADDADE, I. R.; SARAIVA, A.; VITORIA, E. L.; PUPPO, D. D.; SOUZA, E. O. Exigência de lisina digestível e planos de nutrição para frangos de corte machos mantendo as relações metionina + cistina e treonina digestível na proteína ideal. Revista Ciência Rural, Santa Maria, v. 42, n. 3, p. 538-544, 2012.

MAIORKA, A.; BOLELI, I. C.; MACARI, M. Desenvolvimento e reparo da mucosa intestinal. In: MACARI, M.; FURLAN, R. L.; GONZALES, E. (Ed.). Fisiologia Aplicada um aviária frangos de corte. Jaboticabal: FUNEP-Unesp, 2002. p. 113-123.

MENDONÇA, M. O.; SAKOMURA, N. K.; SANTOS, F. R.; BARBOSA, N. A. A.; FERNANDES, J. B. K.; FREITAS, E. R. Níveis de energia metabolizável e relações energia:proteína para aves de corte de crescimento lento criadas em sistema semiconfinado. Acta Scientiarum Animal Sciences, Maringá, v. 29, n. 1, p. 23-30, 2007.

NAMAZU, L. B.; KOBASHIGAWA, E.; ALBUQUERQUE, R.; SCHAMMASS, E. A.; TAKEARA, P.; TRINDADE NETO, M. A. Lisina digestível e zinco quelado para frangos de corte machos: desempenho e retenção de nitrogênio na fase pré-inicial. Revista Brasileira de Zootecnia, Viçosa, MG, v. 37, n. 9, p. 1634-1640, 2008.

ROSTAGNO, H. S.; ALBINO, L. F. T.; DONZELE, J. L.; GOMES, P. C.; OLIVEIRA, R. F.; LOPES, D. C.; FERREIRA, A. S.; BARRETO, S. L. T.; EUCLIDES, R. F. Tabelas brasileiras para aves e suínos: composição de alimentos e exigências nutricionais. Viçosa, MG: Universidade Federal de Viçosa, 2011.

SAKOMURA, N. K.; BIANCHI, M. D.; PIZAURO, J. M.; CAFÉ, M. B.; FREITAS, E. R. Efeito da idade dos frangos de corte sobre a atividade enzimática e digestibilidade dos nutrientes do farelo de soja e soja integral. Revista Brasileira de Zootecnia, Viçosa, MG, v. 33, n. 4, p. 924-935, 2004.
SAKOMURA, N. K.; ROSTAGNO, H. S. Métodos de pesquisa em nutrição de monogástricos. Jaboticabal: FUNEP, 2007. 283 p.

STATISTICAL ANALYSIS SYSTEM INSTITUTE - SAS. SAS Institute Inc. SAS - language reference. Version 8. Cary, NC: SAS Institute Inc, 2001. 1042 p.

SAVOLDI, T. L.; NUNES, R. V.; SCHERER, C.; TSUTSUMI, C. Y.; SCHENEIDERS, J. L.; MARQUES, M. F. G.; SCHONE, R. A.; MEZA, S. K. L. Níveis de energia metabolizável e lisina digestível para o desempenho de pintos de corte de 1 a 10 dias de idade. Scientia Agraria Paranaensis, Cascavel, v. 11, p. 49-58, 2012.

SILVA, D. J.; QUEIROZ, A. C. Análise de alimentos: métodos químicos e biológicos. 3. ed. Viçosa, MG: UFV, 2002. $235 \mathrm{p}$.

TAKEARA, P.; TOLEDO, A. L.; GANDRA, E. R. S. Lisina digestível para frangos de corte machos entre 12 e 22 dias de idade. Arquivo Brasileiro de Medicina Veterinária e Zootecnia, Belo Horizonte, v. 62, n. 6, p. 1455-1461, 2010.

VIEIRA, B. S.; FARIA FILHO, D. E.; TORRES, K. A. A.; BORGES, D. M.; ROSA, P. S.; FURLAN, R. L. Administração in ovo de glutamina e de lisina sobre o desenvolvimento da mucosa intestinal de frangos na primeira semana pós-eclosão. ARS Veterinária, Jaboticabal, v. 22, n. 3, p. 242-247, 2006.

VIOLA, E. S.; VIEIRA, S. L. Suplementação de acidificantes orgânicos e inorgânicos em dietas para frangos de corte: desempenho zootécnico e morfologia intestinal. Revista Brasileira de Zootecnia, Viçosa, MG, v. 36, n. 4, p. 1097-1104, 2007. 